WIDER Working Paper 2014/014

\title{
Employment, unemployment, and underemployment in Africa
}

Stephen Golub and Faraz Hayat*

January 2014 
Abstract: This paper documents and analyses the predominance of informal employment in Africa and shows that lack of demand for labour rather than worker characteristics is the main reason for pervasive underemployment. Integration into the global economy and exports of labour-intensive products are vital to boosting the demand for labour in Africa. Africa has some potential to become competitive in light manufacturing, but the most promising avenue for export-led growth of employment in many African countries is agriculture, including traditional cash crops such as cotton, coffee, cocoa, and groundnuts. Contrary to common perceptions, traditional cash crops, which are the source of livelihood for millions of Africans, have many of the features of manufacturing exports: high labour-intensity; potential for quality improvements through technological transfer; and quality-sensitive markets in developed countries. Improvements in the business climate are the key to boosting investment and technology transfer in labour-intensive tradable industries, and thus raising labour demand and employment.

Keywords: employment, unemployment, underemployment, Africa, labour market, wages.

JEL classification: J2, J3, Q1, O4

Acknowledgements: The authors thank Justin Lin, Celestin Monga, Aly Mbaye, Nancy Benjamin, Howard Pack, Louise Fox, Arne Bigsten, Morten Jerven, and participants in the Beijing conference on the Oxford Handbook of Africa and Economics for comments and discussion.

Note: Figures and Tables at the end of the paper.

\footnotetext{
* Both authors Swarthmore College; corresponding author Stephen Golub: sgolub1@swarthmore.edu

This paper was prepared for the'Oxford Handbook of Africa and Economics' authors' conference in Beijing, 8-10 December 2013, implemented with UNU-WIDER.

Copyright (C) UNU-WIDER 2014

ISSN 1798-7237 ISBN 978-92-9230-735-6

Typescript prepared by Anna-Mari Vesterinen at UNU-WIDER.

UNU-WIDER gratefully acknowledges the financial contributions to the research programme from the governments of Denmark, Finland, Sweden, and the United Kingdom.

The World Institute for Development Economics Research (WIDER) was established by the United Nations University (UNU) as its first research and training centre and started work in Helsinki, Finland in 1985. The Institute undertakes applied research and policy analysis on structural changes affecting the developing and transitional economies, provides a forum for the advocacy of policies leading to robust, equitable and environmentally sustainable growth, and promotes capacity strengthening and training in the field of economic and social policy-making. Work is carried out by staff researchers and visiting scholars in Helsinki and through networks of collaborating scholars and institutions around the world.
}

UNU-WIDER, Katajanokanlaituri 6 B, 00160 Helsinki, Finland, wider.unu.edu

The views expressed in this publication are those of the author(s). Publication does not imply endorsement by the Institute or the United Nations University, nor by the programme/project sponsors, of any of the views expressed. 
Generation of 'good' jobs and economic development are closely connected. Rising labour incomes are the primary means through which growth is translated into improved standards of living and lower poverty rates. Moreover, employment in 'modern' sectors involving skill development and technological learning in turn can promote productivity growth, economic development, and demographic transitions with lower birth rates. The last 50 years have witnessed a virtuous cycle of rapid growth of export-led labour-intensive manufacturing, growth of employment, slowing population growth, as well as rising wages and living standards in a number of emerging countries, particularly in East Asia (e.g., Pack 1988; Radelet et al. 1997; World Bank 1993), as labour has been absorbed into modern industry out of subsistence agriculture and urban informal activities. The most dramatic recent example is of course China where 75 million private sector jobs have been created since China's opening to the global economy, resulting in the largest poverty reduction programme in world history (World Bank 2012: 58).

What about Africa? Much has been made of the emerging 'Cheetah' economies of Africa (e.g., Economist 2011; Radelet 2010) and indeed African growth has picked up substantially since the mid-1990s in many countries and on the continent as a whole. Important strides have been made in health and education indicators. But, relative to other parts of the developing world and in absolute terms, African growth in per capita gross domestic product (GDP) has been limited (Figure 1) and, relatedly, poverty reduction has been disappointing (Figure 2). In part, Africa's slow progress in these regards reflects rapid population growth, offsetting the gains of output growth. In addition, Africa's growth resurgence has entailed limited structural transformation and been driven by capital-intensive mining sectors (Golub et al. 2011; UNCTAD 2010).

African employment consequently remains overwhelmingly informal. This paper documents and analyses the predominance of informal employment and argues that lack of demand for labour is the main problem. Integration into the global economy and exports of labour-intensive products are vital to boosting the demand for labour in Africa. Africa has some potential to become competitive in light manufacturing, but the most promising avenue for export-led growth in many African countries is agriculture, including traditional cash crops such as cotton, coffee, cocoa, and groundnuts. Contrary to common perceptions, traditional cash crops, which are the source of livelihood for millions of Africans, have many of the features of manufacturing exports: high labour-intensity; potential for quality improvements through technological transfer; and lucrative but quality-sensitive markets in developed countries. The same obstacles inhibit traditional and non-traditional agricultural exports as manufacturing: inhospitable business climates characterized by corruption, and high transactions costs and deficient infrastructure. Section 2 presents the basic facts of pervasive underemployment and dualistic labour markets. Section 3 makes the case that underemployment results primarily from lack of demand rather than worker characteristics, Section 4 reviews relevant theoretical models, Section 5 discusses policies for boosting employment and incomes through export-led growth, and Section 6 concludes. 

labour markets

\subsection{Employment and unemployment patterns}

Data on employment in Africa is sparse and not very up to date. The very concepts of labourforce participation, employment, and unemployment used in developed economies are problematic in low-income Africa (Fox and Pimhidzai 2013; Fields 2012). Nevertheless, the available information paints a consistent pattern: African labour markets are marked by sharp dualism with very small formal employment. Agriculture and urban informal sectors 1 feature pervasive underemployment rather than open unemployment. Labourforce participation rates in sub-Saharan Africa (SSA) are not dramatically different from other developing regions, slightly lower for men and surprisingly higher for women compared to Latin America and South Asia although lower than East Asia (Figure 3). The historically unique aspect of African labour markets is the extent of informality (Roubaud and Torelli 2013).

Table 1 shows the distribution of employment into government, formal private sector, and informal sector for selected countries, based on labour market surveys, around 2006. Informal employment is defined here as agricultural work, non-wage-employment, and part-time wage employment. For SSA low-income countries, informal employment defined in this way accounts for at least 80 per cent of total employment, and often $90-95$ per cent. $^{2}$ In half of the lowincome SSA countries shown in Table 1, government employment exceeds formal private sector employment (Benin, Burkina Faso, Cameroon, Mali, Nigeria, Rwanda, Tanzania), whereas in the other half (Ethiopia, Ghana, Malawi, Mali, Senegal, Uganda, Zambia), it is the opposite. In all these countries, however, both formal private and government employment are under 10 per cent, and often below five per cent of the labourforce. Informal employment in middle-income SSA economies Botswana and South Africa is lower, although still sizeable at 38 per cent in both cases. Egypt, typical of North Africa, is an intermediate case, with 61 per cent informal employment, with the bulk of the remainder employed in the public sector (30 per cent).

In a study of the urban informal sectors of ten francophone countries, Roubaud and Torelli (2013) confirm the dominance of informal employment even in the capital cities, finding that on average 77 per cent of these cities' labourforces is informally employed.3.4 Fox et al. (2013) provide a comprehensive analysis of African employment patterns, and find very low levels of wage employment in 2005, typically about 10-15 per cent of the labourforce.

1 As Benjamin and Mbaye (2012) note, definitions of the informal sector differ, with various studies using alternative criteria, including firm size; registration status; tax status; compliance with social security obligations; availability of accounting statements; and fixity of workplace. The overwhelming share of informal employment, however, is not likely to be sensitive to the chosen definition.

2 Informal employment in Table 1 is slightly higher than wage employment in Fox et al. (2013) because informal employment includes some part-time and informal wage employment. See also Footnote 4.

3 Roubaud and Torelli (2013) use the 123 labour market surveys carried out in ten francophone countries during the early- to mid-2000s, the seven members of the West African Economic and Monetary Union (WAEMU)-Benin, Burkina Faso, Côte d'Ivoire, Mali, Senegal, Niger, and Togo)—as well as Madagascar, the DRC, and Cameroon.

4 Informal employment in Roubaud and Torelli (2013) includes some workers employed in the formal sector but there is a high correlation between informal employment and workers in the informal sector- 97 per cent of informal sector jobs are informal while informal employment accounts for 41 per cent of the much smaller number of formal private sector jobs. 
Open unemployment rates are generally very low in low-income SSA (Table 2, around 2006), often well below the levels in developed economies, e.g. 0.7 per cent in Benin, two per cent in Uganda, 2.3 per cent in Burkina Faso, and 2.6 per cent in Madagascar. There are some exceptions, such as Ethiopia, Senegal, and Zambia. Unemployment tends to be higher in middleincome SSA countries, particularly South Africa, whose unemployment problem is notorious (Kingdon and Knight 2004). Also, unlike developed countries, in Africa recorded unemployment rates rise with the level of education, and university graduates tend to have the highest levels of unemployment (African Development Bank 2012). Unemployment is simply not an option for the poor and unskilled, who find refuge in subsistence agriculture and the urban informal sector (Fields 2012). The quality of the unemployment data is open to question, with unemployment and exit from the labourforce difficult to distinguish. Nevertheless, it is clear that Africa has an employment rather than an unemployment problem (Fields 2012).

Following independence, almost all African countries adopted highly interventionist importsubstitution industrialization (ISI) policies characterized by growth of the public sector and protection of domestic industries. Widespread economic crises in the 1980s led to structural adjustment policies involving contraction of the public sector and reduced protection of formal import-competing industries. Public employment declined in absolute terms, and even more so as a share of the labourforce, between the late 1970s and the mid-1990s (Goldsmith 1999). Structural adjustment programmes initially also entailed declines in private sector industrial employment as inefficient import-substituting industries collapsed and non-traditional export growth was disappointing. Since about 1995, African growth has picked up, resulting in rising formal employment, but from a low base (African Development Bank 2012; Fox and Gaal 2008).

There is little systematic information about the evolution of private sector employment, but it is clear that growth of wage employment has been insufficient to make much of a dent in underemployment. Table 3 presents changes over the 1990s or early 2000s in sectoral employment patterns for Tanzania, Uganda, and Nigeria, drawing on the work of Francis Teal and his collaborators (Kingdon et al. 2006; Haywood and Teal 2009). During this time, in all three countries, the share of the labourforce in wage employment (closely related to formal sector employment) declined, due mainly to sharp drops in the shares of public sector employment, including state-owned enterprises. Private sector wage employment grew too slowly to offset these declines in public sector employment, or even to keep up with labourforce growth in some countries, and thus remains very small as a share of the labourforce. Self- and family- (largely urban) employment rose sharply as a share of the labourforce. Wage employment is much lower for women than men. For example, in Uganda in 1999-2000, 16 per cent of men had wage employment but only six per cent of women. In the three countries in Table 3, open unemployment is very low and did not change much over the periods shown. Fox and Gaal (2008) provide similar findings, noting that in Zambia wage employment declined from 25 per cent of the labourforce in the 1970s to less than 10 per cent in 2005.

\subsection{Earnings: dualism and underemployment}

Remuneration differs sharply between the formal and informal sectors in African economies. Table 4 shows that dualism is much greater in low-income Africa than other developing countries, comparing GDP per capita to wages and productivity in manufacturing, for selected 
countries, based on data availability. 5 Productivity and wages in manufacturing are measured as annual value added and labour compensation per employee, respectively, using United Nations Industrial Development Organization (UNIDO) data. ${ }^{6}$ Manufacturing productivity and wages are very high relative to per capita GDP in low-income African countries. The ratio of manufacturing wages to per capita GDP is often about five or higher in these countries, and above two in all cases. For example, in Ghana in 2003, GDP per capita was under US $\$ 400$, manufacturing productivity about US $\$ 10,000$ (20 times per capita GDP), and manufacturing wages close to US $\$ 2,000$ (nearly five times per capita GDP). In middle-income SSA countries and North Africa, the differentials are much smaller, especially in Mauritius. In Asia, particularly East Asia, the ratio of manufacturing wages to per capita GDP is usually not far from parity. In Mexico, the ratio is actually below one. Gelb et al. (2013) and Clarke (2011) also find that African manufacturing wages are very high relative to GDP, using firm-level data.

Roubaud and Torelli (2013) provide further evidence of dualism in African urban labour markets (Table 5). Earnings vary considerably across countries, lowest in the Democratic Republic of Congo (DRC) and highest in Côte d'Ivoire. In almost all cases, however, earnings are generally much higher in the formal public and private sectors than in the informal sector, resulting in extremely high Gini coefficients for labour income. Public enterprise and to a lesser extent general government earnings are particularly high, well above formal private sector earnings, which in turn are typically double to triple informal sector earnings, except in Madagascar, where the differential is narrower. The gap between formal and informal earnings is even more pronounced for women than men. Only a limited portion of these earnings differences are imputable to observable characteristics of workers, such as education, as discussed further in Section 3. Moreover, job tenure is quite long is the formal sector and even in the informal sectors, indicating limited mobility between sectors. Formal sector jobs are primarily held by older workers, which, together with the evidence of limited formal job creation noted above, suggest that the prospects for young people are even dimmer than the overall statistics suggest (African Development Bank 2012). In addition, Roubaud and Torelli (2013) note that the informal sector itself is segmented, as also stressed by Benjamin and Mbaye (2012).

Roubaud and Torelli (2013) document the pervasiveness of underemployment in urban labour markets in francophone Africa, which they divide into 'time-related' underemployment where workers are involuntarily working part-time, and 'invisible' unemployment, defined as those workers who earn less than the minimum wage. Time-related underemployment is rather low, at about 10-15 per cent of the labourforce, given that most workers in the informal as well as formal sectors work full-time jobs averaging close to 50 hours per week. Invisible underemployment is much higher, more than half the labourforce in six of the seven West African Economic and Monetary Union (WAEMU) countries, and about 40 per cent in the nonWAEMU countries. Thus, total urban underemployment is above 50 per cent for all ten countries, averaging 67 per cent in the WAEMU countries, essentially coinciding with informal employment. In addition to low earnings, the vast majority of the workforce in SSA does not receive any social security or other fringe benefits.

\footnotetext{
5 Countries can use varying definitions of these concepts, and the findings in Table 4 should be viewed as general tendencies rather than precise estimates. Also, the formal manufacturing sector is very small in most African lowincome countries. See Mbaye and Golub (2002) and Edwards and Golub (2004) for more discussion of international comparisons of labour costs and productivity.

6 UNIDO labour compensation data do not include employer contributions to social insurance funds and fringe benefits. UNIDO statistics cover only formal firms.
} 
The unsatisfactory nature of African employment opportunities is also manifested in workers' answers to questions about their aspirations. More than half of young workers (ages 15-24) surveyed in the 123 labour market surveys aspire to formal employment in public or private sectors (see Roubaud and Torelli 2013, Table 1.25), despite the paucity of formal job creation. The African Development Bank (2012), using Gallop poll data, provides similar evidence of mismatch between aspirations of young people and the realities of the job market.

In summary, since the era of structural adjustment, employment opportunities in the public sector have dwindled and the formal private sector has failed to grow sufficiently to absorb the large majority of the working population in agriculture and the urban informal sector, earning very low incomes and lacking access to social insurance programmes. At the time of writing his classic article, Arthur Lewis (1954) noted that much of Africa did not fully fit his model of unlimited supply of labour in subsistence activities. However, due to rapid population growth combined with limited development of the formal sector, Lewis's framework now fits very well for much of low-income Africa, dominated by subsistence agriculture and small-scale informal family firms:

What we have is not one island of expanding capitalist employment surrounded by a vast sea of subsistence workers, but rather a number of such tiny islands. ... We find a few industries highly capitalized such as mining or electric power side by side with most primitive techniques, a few high class shops surrounded by masses of old style traders, a few highly capitalized plantations, surrounded by a sea of peasants. (p. 147).

\section{Causes of dualism and underemployment in Africa}

There are two main explanations for the large differentials in earnings and pervasive underemployment described above: 1) heterogeneous labour, with the preponderance of the labourforce having low human capital and limited skills and 2) low demand for labour combined with labour market segmentation. The labour heterogeneity argument claims that differences in human capital and other worker characteristics explain income differentials. The segmentation argument shifts the focus to the product markets with a shortage of good jobs, and rationing of these jobs. It is important to ascertain which of these two explanations is relatively more important in Africa, although of course both likely have some validity. If higher wages depend on raising human capital then the focus of poverty-reduction strategies on education and health in Africa is appropriate. If, however, low demand for labour originates in the product market, improved educational attainments and health outcomes may not be sufficient to boost formal employment, and the focus instead should be on the business climate.

The observed patterns of wages and employment suggest that low demand for labour is the primary cause. In general, education explains only about 30 per cent of variations in labour compensation (Mortensen 2005). Although this may reflect unobservable labour skills (Rosenzweig 1988), Mortensen (2005) finds that labour heterogeneity is robust to inclusion of numerous controls. Teal (2011) cites recent evidence showing that segmentation is common in African labour markets, particularly between firms of different sizes. Söderbom et al. (2002) show that when observable and unobservable aspects of human capital are controlled for, wages are much higher in larger firms. Kingdon et al. (2006) conclude that non-competitive theories such as efficiency wages and bargaining models explain this effect better than human capital 
theory. In the formal manufacturing sector, Fox and Oviedo (2008) show that wage premia do not reflect productivity differences.

Enterprise surveys and poll data provide further evidence that low demand for labour rather than lack of education is the most binding constraint. Respondents to enterprise surveys in Africa tend not to rate lack of education of the labourforce as one of the top constraints. The African Development Bank (2012) used Gallop Poll Surveys conducted in 10 North African countries (African Development Bank 2012), finding that factors relating to insufficient labour demand (lack of jobs; insufficient government efforts; weak economy; jobs being given to people with connections; and corruption) together account for about two-thirds of the reasons provided. Secondary and tertiary education improves the chances of having wage employment, but even for workers with university education, underemployment and unemployment is the norm. The African Development Bank (2012) reports that only 30 per cent of young people with some tertiary education hold wage employment, while another 30 per cent are in 'vulnerable employment', and the remaining 40 per cent are unemployed, inactive or discouraged. Open unemployment actually rises with education, as previously noted.

Several other factors contribute to low formal employment. 1) Education may be expanding, but fail to impart useful skills (Page 2012; African Development Bank 2012), creating a mismatch between worker skills and employer needs. 2) Rapid population growth exacerbates the excess supply of labour in Africa (Fox et al. 2013), offsetting the effects of output growth. To some extent, however, Africa's failure to experience a demographic transition reflects the lack of structural transformation so cause and effect are difficult to distinguish. 3) wages could be driven up by Dutch Disease effects in some natural-resource abundant countries driving up wages, but this cannot explain why informal sector labour incomes are so low relative to formal-sector wages. Moreover, natural resource abundance does not necessarily preclude labour-intensive manufacturing exports, as Malaysia and Indonesia have shown (Fox et al. 2013).

\section{$4 \quad$ Models of dualism and underemployment}

In light of the evidence in the previous section on dualism, we now review the theoretical literature on causes and remedies for widespread underemployment and low earnings.

\subsection{Dualism and structural transformation: the Lewis model}

The celebrated Lewis (1954) model still provides the starting point for understanding African dualism as resulting from low demand for labour in the modern sector. The model features a large traditional sector with subsistence incomes and a small modern sector paying much higher wages. The process of economic development involves expansion of the modern (formal) sector through capital accumulation, gradually absorbing surplus labour from the subsistence (informal) sector.

Figure 4 depicts the intersectoral allocation of labour in the Lewis model between rural ( $r$ ) and modern (m) sectors. ${ }^{7} \mathrm{~L}$ represents the total labourforce, MPL is the marginal productivity of labour, and W the real wage. Due to a 'surplus' of labour, $\mathrm{MPL}_{\mathrm{r}}$ is very low, with the modern

\footnotetext{
7 The figure is based on Basu (1997). This version assumes that wages equal the marginal productivity of labour in the traditional sector, ignoring Lewis' point that earnings are equal to average rather than marginal product. This distinction is of little significance for the intersectoral dynamics that we focus on here.
} 
sector consequently facing a perfectly elastic supply of labour. For reasons not specified in Lewis (1954), however, $\mathrm{W}_{\mathrm{m}}$ is set exogenously well above the subsistence level $\mathrm{W}_{\mathrm{r}}$. Initially, as the modern sector invests, raising $\mathrm{MPL}_{\mathrm{m}}$, its employment expands, e.g., from $\mathrm{L}_{1}$ to $\mathrm{L}_{2}$, absorbing labour from the traditional sector without raising $\mathrm{W}_{\mathrm{r}}$. Eventually, the absorption of labour in the modern sector reaches $\mathrm{L}_{3}$, the Lewis turning point, and incomes begin to rise above subsistence levels in the traditional sector.

The modern sector's output may be modeled using the a Cobb-Douglas function (subscript $\mathrm{m}$ suppressed), $Q=F(A, K, L)=A K^{\alpha} L^{1-\alpha}$

where $\mathrm{A}$ is technology, $\mathrm{K}$ is capital and $\mathrm{L}$ is labour. Labour market equilibrium implies $M P L=W$.

Denoting $\dot{L}=\frac{d L / d t}{L}$ and likewise for other variables, it is easy to show that:

$$
\dot{L}=\frac{\dot{A}+\alpha \dot{K}-\dot{W}}{\alpha}
$$

That is, the rate of growth of modern-sector employment depends on technological progress, capital accumulation and real wage moderation.

\subsection{Urban unemployment and informal employment}

Harris and Todaro (1970) (HT) elaborated on Lewis's dualistic labour market to include largescale urban unemployment and underemployment, making migration endogenous. Surplus rural labour migrates to the higher-paid urban (modern) sector as long as the expected urban wage is higher than the rural wage. Equilibrium occurs when expected wages are equalized through adjustments in unemployment. That is, rural-urban migration continues until unemployment rises such that the probability of a finding a high-paying job falls enough to equalize expected urban and rural wages.

Figure 5 depicts the HT model. HH represents a rectangular hyperbola on which the rural equilibrium wage and employment level lie, for a given modern sector wage and employment level. Equilibrium may be stated as:

$$
W_{m} \frac{L_{m}}{L-L_{r}}=W_{r}
$$

where $L-L_{r}$ is the urban labourforce and $\frac{L_{m}}{L-L_{r}}$ is the probability of finding a job in the modern sector.

Fields $(1975,1990)$ presented a further important extension of the HT model, distinguishing unemployment and informal employment. The economy's labourforce is now composed of four groups: workers in the urban modern sector; workers in the urban informal sector; the urban unemployed; and subsistence agriculture. In Fields' model, taking a low-paying urban informal job facilitates searching for a modern-sector job relative to remaining in the countryside, although unemployed workers face even-lower search costs. Fields' (1975) framework implies that urban informal earnings are below rural incomes, although superior to incomes of the 
unemployed. In reality, urban informal incomes are higher than in agriculture (Fox and Gaal 2008), but real incomes of the urban informal sector could still be lower, considering the higher pecuniary and non-pecuniary costs of urban living relative to village life.

Both the Lewis and HT models assume but do not explain the reasons for high and sticky modern sector wages. These high wages could be due to minimum wages, unions, or efficiency wage considerations. The labour turnover model (Stiglitz 1974) proposes that firms pay higher wages to reduce quit rates. Alternatively, the biological efficiency wage model (Stiglitz 1976) assumes that firms pay higher wages so that workers have enough nutrition to work productively and avoid illness.

The HT model and Fields extension, show how surplus labour is manifested in open unemployment and urban informal employment, in addition to subsistence agriculture. The central underlying problem giving rise to dualism, however, remains the scarcity of relatively high-paying modern sector jobs, as stressed by Lewis (1954).

\subsection{The roles of globalization and modernization of the informal sector}

Two important extensions to the Lewis perspective are relevant to contemporary Africa; 1) the role of globalization in accelerating structural transformation, and 2) modernization of informal practices, especially in agriculture, through technology transfer.

Globalization. In the original Lewis (1954) model, the speed of economic development depends on domestic capital investment and technological change in the modern sector. ${ }^{8}$ Fei and Ranis (1964) and others extended the Lewis model by refining the intersectoral linkages and the role of agriculture, while still assuming a closed economy. Contemporary globalization requires some important amendments to the Lewis and Fei-Ranis framework, through two channels: a) Foreign capital, particularly foreign direct investment (FDI), provides an alternative to domestic savings and technological change. Moreover, FDI provides higher-paying jobs, increased competition, more training, and knowledge spillovers (Javorcik 2012). b) Outsourcing of labour-intensive manufactured products such as apparel by global supply chains (e.g., Gereffi 1999) also raises the demand for labour in developing countries. Murphy et al. (1989) is in the spirit of Lewis (1954), allowing for exports but with costly access to foreign markets. Thus, the central problem becomes alleviating bottlenecks to labour-intensive exports. Golub et al. (2007) point to the importance of domestic 'service links', i.e. infrastructure and public services, in enabling developing countries to participate in the international fragmentation of production. Viewed from this perspective, accelerating growth of the modern sector requires improvement of the business climate in order to attract FDI and other 'footloose' inputs that are critical to global competitiveness in manufacturing.

Modernization of the urban informal sector and agriculture. Lewis (1954) focused on shifting out modern sector labour demand but another possibility is to raise productivity in agriculture and the informal sector, shifting the demand for labour in the rural sector. Lewis himself recognized that the distinction between traditional and modern activities did not coincide with rural and urban, as shown by the quote above. Much attention now focuses on raising productivity of the urban informal sector (e.g. Fox and Sohnesen 2012) but agriculture may be more promising. The

\footnotetext{
8 Lewis (1954) extended the analysis to international trade, but focused on the adverse implications of 'unlimited supply' of labour for the terms of trade, rather than on export-led growth's potential to shift urban labour demand. Of course this was before the East Asian 'miracle' began in the $1960 \mathrm{~s}$.
} 
products of the urban informal sector are predominantly non-tradable services or artisanal manufacturing, with minimal exporting. Exports of traditional and non-traditional agricultural cash crops, however, are a viable African alternative to manufacturing for labour-intensive export-led growth (Golub et al. 2008; Brenton et al. 2009). This issue is discussed in more detail in the next section.

\section{Expanding employment through labour-intensive non-traditional exports in Africa}

The previous sections have argued that raising labour demand is the central route to poverty alleviation, and that the experience of the last 50 years in East Asian and other emerging economies suggests that this can best be attained through labour-intensive exports, facilitated by foreign technology and investment. In Africa, domestic markets are very small, making exports even more essential.

Export-led growth is often identified with manufacturing, based on East Asia's and to a lesser extent Latin America's successes. Collier (2008) is pessimistic about Africa's ability to compete with Asian manufacturers, given their head start and competitive advantages. Dinh et al. (2012) argue that Africa can compete in some light manufacturing industries, but that weaknesses in the business climate must be remedied.

Alternates to manufacturing for labour-intensive exports are available, as demonstrated by India's booming exports of business services. Africa has promising export industries in tourism, fishing and especially agriculture, including horticulture (fruits, vegetables, and cut flowers) and perhaps most significantly, traditional cash crops.

Agricultural exports share many of the features of manufacturing, both in terms of their potential to spur growth and employment, and the institutional constraints they face in achieving this potential. Several critical aspects of manufacturing exports promoting development and poverty reduction apply to traditional and non-traditional agriculture: 1) high labour-intensity; 2) possibilities for technological upgrading and consequently raising producer incomes; 3) access to state-of-the-art foreign technology through FDI and outsourcing; 4) the necessity of attaining international competitiveness; and thus 5) the critical roles of low-cost labour and a favourable climate for investment. For agriculture, especially, sanitary and phyto-sanitary norms in developed country markets are a major hurdle for successful exporting (Golub and McManus 2008) analogous to the demanding specifications of global buyers of apparel (Gereffi 1999).

The augmented Lewis model in Section 4 suggests two main institutional impediments to labourintensive exports: 1) wages are set too high in the modern sector; and 2) the adverse business climate deters investment and technological upgrading in labour-intensive tradable industries, both in manufacturing and agriculture.

High labour costs. Minimum wages, unions, and labour market restrictions can raise urban labour costs, reducing employment in the formal sector as firms adopt more capital-intensive techniques or exit the country (Equation 1 in Section 4.1). As shown in Section 2.2, manufacturing wages in Africa are very high relative to per capita income and informal sector incomes. This is partly due to relatively high minimum wages and labour market restrictions. Table 6 shows that minimum wages relative to GDP are much higher in most low-income African countries than in other regions, particularly East Asia. This is not the case for the middle-income African countries, although South Africa has rather high manufacturing wages, 
likely due in part to strong unions rather than minimum wages. Minimum wages may therefore be part of the explanation for high manufacturing wages relative to GDP in low-income African countries.

Some studies (e.g., Rama 2000; Fox and Oviedo 2013) have found that minimum wages and labour market restrictions are not a major constraint in Africa, unlike in other regions, despite often highly restrictive statutory provisions, perhaps because of lack of enforcement or because other constraints are more important. This benign perspective on labour market regulations may be overstated for several reasons. First, labour market conflicts may be of lesser importance than infrastructure or corruption, but could still matter. Second, domestic firms, particularly in the informal sector, may be able to routinely disregard labour market statutes. Formal firms, especially foreign investors, however, may feel compelled to abide by local laws, due to lesser recourse to authority in the host country as well as pressures from labour-rights activists at home, and thus may simply eschew investing in countries with such laws even if they are not much enforced. Moreover these laws may be enforced more vigorously for large formal firms or those lacking in political or kinship group connections. Golub and Mbaye (2002) found that large formal firms in Senegal cite legal conflicts with labour unions over dismissals and work rules as a significant problem.

As noted in Section 2.2, both wages and productivity in manufacturing are high in Africa relative to per capita GDP. Unit labour costs, the ratio of wages to productivity, also tend to be higher in Africa than in other developing regions, adversely affecting international competitiveness (Mbaye and Golub 2002; Edwards and Golub (2004); Clarke 2011; Gelb et al. 2013). One possible way of improving competitiveness, adopted in East Asia, is to promote exchange-rate undervaluation, but this is precluded in countries in monetary unions, as in francophone west and central Africa.

Business climate for investment. More importantly than labour market restrictions, the African business climate remains very problematic in some areas, notably poor infrastructure and public services as well as burdensome restrictions and regulations (Ramachandran et al. 2009; Eifert et al. 2008). Deficiencies in infrastructure, red tape, and corruption raise indirect costs of production, input sourcing, and distribution substantially.

Table 7 provides some measures of the quality of infrastructure and public services in selected countries: number of days of power outages; time to obtain a fixed-line telephone connection; time to clear an imported container through customs; and percentage of roads that are paved. In all of these categories, low-income SSA countries comparare unfavourably to other developing regions, except South Asia, also known for very poor infrastructure. The contrast is most dramatic for power outages, often ranked as the number one constraint by firms in Africa (Ramachandran et al. 2009). Low-income African countries mostly rank at the bottom of standard measures of competitiveness and the business climate, such as the World Bank's Doing Business indexes.

At a deeper level, poor business climates are a manifestation of weak states. As Lin and Monga (2010); Rodrik (2008); Golub et al. (2011), UNCTAD (2010), and others have stressed, the private sector is the engine of job creation, but economic development requires a 'developmental state' that assists the private sector to overcome market failures, such as external economies of scale, co-ordination failures, and knowledge externalities. In particular, industrial policies are needed to assist promising infant industries. Yet in African countries, state failures are often even worse than market failures. These state failures take the form of both errors of omission (failure to invest in infrastructure and provide public services) and commission (excessive regulation and predation on private businesses) (Krueger 1990). In an environment with pervasive market 
failures and government failures, it is very difficult to foster formal-sector entrepreneurship and fixed investment. While considerable progress has occurred in reducing administrative complexity and improving public services, much remains to be done.

These institutional dysfunctions raise transaction costs in all areas of economic activity, but are particularly damaging for export-oriented industries where quality control and timeliness of delivery are paramount. Collier (1998) and Golub et al. (2007) attribute Africa's failure to attract investment in labour-intensive manufacturing to state failures raising transaction costs. It is less well known that traditional cash crop production is also undermined by severe disorganization resulting from state failures.

Agricultural primary products, such as cotton, coffee, cocoa, and groundnuts, still dominate exports of many African countries, affecting the livelihoods of very large numbers of people, often small-holder farmers. These products involve complex value chains, including research and extension, provision of credit and inputs (seeds and fertilizer), storage, collection of the crop, transport, processing (e.g., shelling peanuts or ginning cotton) and marketing, in addition to planting and harvesting. Particularly for small-holders, arrangements for provision of credit and repayment of loans are major issues. Smallholder farming requires organization and assistance from either large private firms or the state for input provision and quality control that is difficult to reconcile with decentralized competition. Inputs are typically provided on credit, with the loans being repaid through a deduction from the purchase price at the time of collection. Pricesetting is also complex. Clearly, opportunistic behaviour by farmers as well as input providers is a potential serious threat to the viability of such an integrated system. Consequently, as Poulton et al. (2004) and Tschirley et al. (2009) have documented for cotton, there is a fundamental tradeoff between competition and co-ordination in the organization of the value chain. Various forms of organization ranging from state ownership to private monopoly and decentralized competition are possible, but some form of co-ordination is necessary. Rules and property rights must be clear and enforced, thus providing an essential role for the state, regardless of the system.

Exports of specialty coffees, e.g., in Rwanda, illustrate the potential gains from exports of agricultural commodities through technological transfer and product upgrading (Golub et al. 2008). But more often, the same institutional obstacles to manufacturing competitiveness block progress in agriculture, as illustrated by the cases of cotton in Benin and groundnuts in The Gambia and Senegal. As in other countries, these cash crops were controlled by state marketing boards in the first decades of independence and privatized in the 1990s and 2000s. The integrated state-controlled system was evidently flawed, but reforms have had mixed success. Opening the market has often entailed opportunistic behaviour rather than open competition. Provision of public goods has suffered.

Cotton in Benin. The farming, transport, and processing of cotton contributes directly and indirectly to the livelihoods of some 60 per cent of the population in Benin. Benin and other countries in West Africa have an ideal climate for cotton and can produce organic hand picked cotton, which if handled appropriately, can command high prices. With assistance from the World Bank in the 1990s, Benin phased in a complex system of private organization, involving limited competition. The reforms succeeded in spurring the entry of domestic entrepreneurs. Some of these entrepreneurs have proved effective, while others have been incompetent and opportunistic, relying on political connections to remain in business. Indeed, the government has failed to enforce the rules and sanction cheaters. Instead, it has sometimes intervened in support of special interests and disrupted the functioning of the system. Benin suffers in some respects from the worst of both worlds: limited co-ordination, due to the weakness of the institutions in 
enforcing compliance, and limited competition, resulting in depressed production and incomes. The problem is not so much the design of the reforms but the government's inability to implement them effectively (Golub 2009).

Groundnuts in Senegal/The Gambia. Groundnuts remain the two countries' dominant cash crop. In The Gambia, over 80 per cent of the population is involved in groundnut production, handling, processing, and marketing directly or indirectly, and the crop occupies 40 per cent of the land under cultivation. In Senegal, the proportion of land devoted to groundnuts is similar although the share of groundnuts in exports and GDP have declined considerably over time (Golub and Mbaye 2002; Mbaye 2005; Integrated Framework 2007). Groundnuts can be sold in either edible form or processed into peanut oil and oil-cake. Contrary to the view that developing countries should strive for greater processing rather than selling products in raw form, edible groundnuts can fetch much higher prices in the European market than groundnuts pressed into oil. However, concerns about aflatoxins 9 and pesticide residues have ratcheted up the quality standards in the edibles market, with higher qualities commanding increasing premiums. Processes for controlling aflatoxins are well-known and not particularly difficult to implement in purely technical terms, requiring attention to moisture control and rapid shipment, in turn demanding investment in storage and transport infrastructure, and training of personnel in proper handling (Mbaye 2005). Senegal and The Gambia have made little or no progress in these areas, so Senegalese and Gambian edible groundnuts have very elevated aflatoxin levels and have thus largely been shut out of the European market.10

Cotton in Benin and groundnuts in The Gambia and Senegal illustrate the disorganization and opportunistic behaviour that undermine potentially lucrative exports, arising in an environment characterized by corruption, failure to provide or upgrade infrastructure, and lack of contract enforcement. Clearly, effective functioning of integrated systems requires a government that invests in public goods, does not intervene arbitrarily and enforces the rules of the system.

In summary, state failures and the resulting weaknesses of the business environment in Benin, The Gambia, and Senegal, and many other countries, are at the root of the paucity of employment opportunities in both modern and traditional sectors. In a globalized world, the rewards for good governance are great, but failures are heavily penalized.

\section{$6 \quad$ Conclusions}

African economies have picked up but structural transformation remains limited. In this setting, employment opportunities are barely keeping up with rapidly growing labourforces. In lowincome countries, this translates into large and sometimes growing underemployment rather than open unemployment, as people are simply too poor not to work. The vast majority of the workforce remains in subsistence agriculture and, increasingly, the urban informal sector, with very low and uncertain incomes and no access to social insurance programmes. Public sector jobs have dwindled since the era of structural adjustment in the 1980s and 1990s, and private formal sector employment growth has been too small and started from too low a base to make a significant dent in underemployment. With its rapidly growing populations, small enclaves of relatively well-paying modern sectors, and vast informal economies, Africa resembles the

\footnotetext{
9 Aflatoxins are a known cancer-causing substance that contaminates groundnuts when handling and storaging are slow and the crop is exposed to inappropriate moisture and temperature.

10 Gambian raw groundnuts have been sold at discounted prices for birdseed, but even this limited market is threatened as animal rights activists protest against exposure of birds to high levels of aflatoxins!
} 
situation described by Arthur Lewis (1954) as 'unlimited supply of labour' more so today than at the time Lewis presented his classic analysis.

Lewis' (1954) depiction of development as the absorption of underemployed labour from subsistence activities into modern industry is still valid, with two amendments. First, developing countries can harness the forces of globalization to generate unprecedentedly rapid growth through labour-intensive exports, as successive waves of East Asian countries have been demonstrating for 50 years. Second, exports of traditional and non-traditional agricultural crops, tourism, and fishing are viable alternatives to manufacturing in Africa. Africa has opportunities to benefit from globalization, in manufacturing but even more in agriculture. In a competitive world market, however, success depends on strict quality control and timeliness of delivery. Private firms, including foreign investors, can supply capital, entrepreneurship and technology, but require an enabling environment and public goods-contract enforcement, technical assistance, and adequate infrastructure. When the government fails to provide public goods and harasses formal-sector firms, domestic enterprises will shut down or become informal, and foreign investors will look elsewhere. The workforce pays the price in the form of fewer employment opportunities and lower incomes. Many African countries have made considerable progress in restoring macroeconomic stability and improving the business environment, but further efforts are needed to attain global competitiveness in labour-intensive industries to spur sustained employment growth and rising earnings.

\section{References}

African Development Bank (2012). African Economic Outlook 2012: Promoting Youth Employment. Tunis: African Development Bank.

As'ad, R. (2009). The Egyptian Labor Market Revisited. Cairo: American University in Cairo Press.

Basu, K. (1997). Analytical Development Economics: the Less Developed Economy Revisited. Cambridge, MA: MIT Press.

Benjamin, N. and A. Mbaye (2012). The Informal Sector in Francophone Africa: Firm Size, Productivity and Institutions. Washington, DC: World Bank.

Brenton, P., R. Newfarmer, and P. Walkenhorst (2009). 'Avenues for Export Diversification: Issues for Low-Income Countries'. MPRA, Commission on Growth and Development Working Paper 47. Munich: MPRA.

Clarke, G. (2011). 'Wages and Productivity in Manufacturing in Africa: Some Stylized Facts'. Background paper III for Dinh, H.T., V. Palmade, V. Chandra, and F. Cossar (eds), Light Manufacturing in Africa: Targeted Policies to Enhance Private Investment and Jobs. Washington, DC: World Bank.

Collier, P. (2008). 'Growth Strategies for Africa'. Commission on Growth and Development Working Paper 9.

Collier, P. (1998). 'Globalization: Implications for Africa'. In Z. Iqbal and M.S. Khan (eds), Trade Reform and Regional Integration in Africa. Washington, DC: IMF.

Data Portal Ghana (2010). Data Portal Ghana. Accessed August 2013. http://data.gov.gh/

Dinh, H.T., V. Palmade, V. Chandra, and F. Cossar (2012). Light Manufacturing in Africa: Targeted Policies to Enhance Private Investment and Jobs. Washington, DC: World Bank.

Economist (2011). 'Africa's Hopeful Economies: The Sun Shines Bright'. 3 December 2011. 
Edwards, L. and S.S. Golub (2004). 'South Africa's International Cost Competitiveness and Exports in Manufacturing'. World Development, 32(8): 1323-39.

Eifert, B., A. Gelb, and V. Ramachandran (2008). 'The Cost of Doing Business in Africa: Evidence from the Investment Climate Data'. World Development, 36(9): 1531-46.

Fei, J.C.H. and G. Ranis (1964). Development of the Labor and Surplus Economy: Theory and Policy. Homewood: Irwin.

Fields, G.S. (2012). Working Hard, Working Poor. New York: Oxford.

Fields, G.S. (1990). 'Labor Market Modelling and the Urban Informal Sector: Theory and Evidence'. In D. Turnham, B. Salomé, and A. Schwartz (eds), The Informal Sector Revisited. Paris: OECD.

Fields, G.S. (1975). 'Rural-urban Migration, Urban Unemployment and Under-development, and Job-search Security in LDCs'. Journal of Development Economics, 2(2): 165-87.

Fox, L. and M.S. Gaal (2008). Working Out of Poverty: Job Creation and the Quality of Growth in Africa. Washington, DC: World Bank.

Fox, L. and A.M. Oviedo (2013). 'Institutions and Job Growth in African Manufacturing: Does Employment Protection Regulation Matter?'. Journal of African Economies, 22(4): 616-50.

Fox, L. and A.M. Oviedo (2008). 'Are Skills Rewarded in Sub-Saharan Africa'. World Bank Policy Research Working Paper 4688. Washington, DC: World Bank.

Fox, L. and O. Pimhidzai (2013). 'Different Dreams, Same Bed: Collecting, Using, and Interpreting Employment Statistics in Sub-Saharan Africa-The Case of Uganda'. World Bank Policy Research Working Paper 6184. Washington, DC: World Bank.

Fox, L. and T.P. Sohnesen (2012). 'Household Enterprises in Sub-Saharan Africa: Why They Matter for Growth, Jobs, and Livelihoods'. World Bank Policy Research Working Paper 6184. Washington, DC: World Bank.

Fox, L., C. Haines, J.H. Muñoz, and A. Thomas (2013). 'Africa's Got Work to Do: Employment Prospects in the New Century’. IMF Working Paper 13/201. Washington, DC: IMF.

Gelb, A., C. Meyer, and V. Ramachandran (2013). 'Does Poor Mean Cheap? A Comparative Look at Africa’s Industrial Labor Costs'. Mimeo. Center for Global Development.

Gereffi, G. (1999). 'International Trade and Industrial Upgrading in the Apparel Commodity Chain'. Journal of International Economics, 48(1): 37-70.

Goldsmith, A.A. (1999). 'Africa's Overgrown State Reconsidered: Bureaucracy and Economic Growth'. World Politics, 51(04): 520-46.

Golub, S.S. (2009). 'Specific Constraints in the Cotton and Transit Trade Sectors'. In Benin Country Economic Memorandum. Washington, DC: World Bank.

Golub, S.S. and J. McManus (2008). 'Horticulture Exports and African Development'. Paper prepared for UNCTAD. Mimeo.

Golub, S.S. and A.A. Mbaye (2002). 'Obstacles and Opportunities for Senegal's International Competitiveness: Case Studies of the Peanut Oil, Fishing and Textile Industries'. World Bank Africa Region Working Paper 37. Washington, DC: World Bank.

Golub, S.S., A. Bernhardt, and M. Liu (2011). 'Development and Trade Strategies for Least Developed Countries.'. Paper prepared for UNCTAD. Mimeo. 
Golub, S.S., R. Jones, and H. Kierzkowski (2007). 'Globalization and Country-Specific Service Links'. Journal of Economic Policy Reform, 10(2): 63-88.

Golub, SS., S.A. O'Connell, and W. Du (2008). 'Export Competitiveness and Development in LDCs: Policies, Issues, and Priorities for Least Developed Countries'. UNCTAD. unctad.org/en/docs/aldc20081_en.pdf

Harris, J.R. and M.P. Todaro (1970). 'Migration, Unemployment and Development: A TwoSector Analysis'. American Economic Review, 60(1): 126-42.

Haywood, L. and F. Teal (2009). 'Employment, Unemployment and Incomes in Nigeria: 19992006'. Center for the Study of African Economies, report prepared for the World Bank. Mimeo.

Integrated Framework (2007). The Gambia: From Entrepot to Exporter and Eco-Tourism. Diagnostic Trade Integration Study, July. www.enhancedif.org/en/system/files/uploads/gambia_dtis_final_july07.pdf

Javorcik, B.S. (2012). 'Does FDI Bring Good Jobs to Host Countries?'. Background Paper for the World Bank World Development Report 2013.

Kingdon G. and J. Knight (2004). 'Unemployment in South Africa: The Nature of the Beast'. World Development, 32(4): 391-408.

Kingdon, G., J. Sandefur, and F. Teal (2006). 'Labor Market Flexibility, Wages, and Incomes in Sub-Saharan Africa in the 1990s’. African Development Review, 18(3): 392-427.

Krueger, A.O. (1990). 'Government Failures in Development'. Journal of Economic Perspectives, 4(3): 9-23.

Lewis, W.A. (1954). 'Economic Development with Unlimited Supplies of Labour'. Manchester School, 22(2): 139-91.

Lin, J.Y. and C. Monga (2010). 'Growth Identification and Facilitation: The Role of the State in the Dynamics of Structural Change'. World Bank Policy Research Working Paper 5313. Washington, DC: World Bank.

Mbaye, A.A. (2005). 'Sanitary and Phytosanitary Requirements and Developing Country Agro Food exports: An Assessment of the Senegalese Groundnut Sector'. World Bank Agriculture and Rural Development Discussion Paper. Washington, DC: World Bank.

Mbaye, A.A. and S.S. Golub (2002). 'Unit Labor Costs, International Competitiveness, and Exports: the Case of Senegal'. Journal of African Economies, 11(2): 219-48.

Mortensen, D. (2005). Wage Dispersion: Why Are Similar Workers Paid Differently. Cambridge: MIT Press.

Murphy, K.M., A. Shleifer, and R.W. Vishny (1989). 'Industrialization and the Big Push'. Journal of Political Economy, 97(5): 1003-26.

Pack, H. (1988). 'Industrialization and Trade'. In H. Chenery and T.N. Srinivasan (eds), Handbook of Development Economics Volume I. Amsterdam: North Holland.

Page, J. (2012). 'Youth, Jobs, and Structural Change: Confronting Africa's 'Employment Problem'. African Development Bank Working Paper 155. Tunis: AfDB.

Poulton, C., P. Gibbon, B. Hanyani-Mlambo, J. Kydd, W. Maro, M. Nyulansted Larsen, A. Osorio, D. Tschirley, and B. Zulu (2004). 'Competition and Coordination in Liberalized African Cotton Market Systems’. World Development, 32 (3): 519-36. 
Radelet, S. (2010). Emerging Africa: How 17 Countries are Leading the Way. Washington, DC: Center for Global Development.

Radelet, S., J. Sachs, and J.-W. Lee (1997). 'Economic Growth in Asia'. HIID Development Discussion Paper 609, November.

Rama, M. (2000). 'Wage Misalignment in CFA Countries: Were Labor Market Policies to Blame'. Journal of African Economies, 9(4): 475-511.

Ramachandran, V., A. Gelb, and M.K. Shah (2009). Africa's Private Sector: What's Wrong with the Business Environment and What to Do about It. Washington, DC: Center for Global Development.

Razafindrakoto, M., F. Roubaud, and C. Torelli (2009). 'Measuring the Informal Sector and Informal Employment: the Experience Drawn from 1-2-3 Surveys in African countries'. Paris: Université Paris Dauphine.

Rodrik, D. (2008). 'Normalizing Industrial Policy'. Commission on Growth and Development Working Paper 3. Washington, DC: World Bank.

Rosenzweig, M.R. (1988). 'Labor Markets in Low-Income Countries'. In H. Chenery and T.N. Srinivasan (eds), Handbook of Development Economics, Volume I. Amsterdam: North Holland.

Roubaud, F. and C. Torelli (2013). 'Employment, Unemployment and Working Conditions in Urban Labor Markets of Sub-Saharan Africa: Main Stylized Facts'. In P. de Vreyer and F. Roubaud (eds), Urban Labor Markets in Sub-Saharan Africa. Washington, DC: World Bank.

Söderbom, M., F. Teal, and A. Wambugu (2002). 'Does Firm Size Really Affect Earnings?'. CSAE WPS/2002-08. Oxford: University of Oxford.

Stampini, M., R. Leung, S.M. Diarra, and L. Pla (2013). 'How Large is the Private Sector in Africa? Evidence from National Accounts and Labour Markets'. South African Journal of Economics, 81(1): 140-65.

Stiglitz, J.E. (1976). 'The Efficiency Wage Hypothesis, Surplus Labor, and the Distribution of Income in LDCs'. Oxford Economic Papers, 28(2): 185-207.

Stiglitz, J.E. (1974). 'Alternative Theories of Wage Determination and Unemployment in LDCs: The Labor Turnover Model'. Quarterly Journal of Economics, 88(2): 194-227.

Teal, F. (2011). 'The Price of Labour and Understanding the Causes of Poverty'. Labour Economics, 18: S7-S15.

Tschirley, D., C. Poulton, and P. Labaste (2009). Organization and Performance of Cotton Sectors in Africa. Washington, DC: World Bank.

UNCTAD (2010). The Least Developed Countries Report 2010: Towards a New International Development Architecture for LDCs. Geneva: UNCTAD.

UNIDO (2012). Industrial Statistics Database. United Nations Industrial Development Organization, CD-ROM.

United States Department of State (2013). U.S. Department of State. http://www.state.gov/

Van Klaveren, M., K. Tijdens, M. Hughie-Williams, and N.R. Martin (2009a). 'An Overview of Women's Work and Employment in Botswana'. AIAS Working Paper 09-81. Amsterdam: AIAS. 
Van Klaveren, M., K. Tijdens, M. Hughie-Williams, and N.R. Martin (2009b). 'An Overview of Women's Work and Employment in Zambia'. AIAS Working Paper 09-80. Amsterdam: AIAS.

World Bank (2013a). Enterprise Surveys. http:/ /www.enterprisesurveys.org.

World Bank (2013b). World Development Indicators. Washington, DC: World Bank.

World Bank (2012). World Development Report 2013: Jobs. Washington, DC: World Bank.

World Bank (1993). The East Asian Miracle. Washington, DC: World Bank.

Figure 1: GDP per capita: developing regions

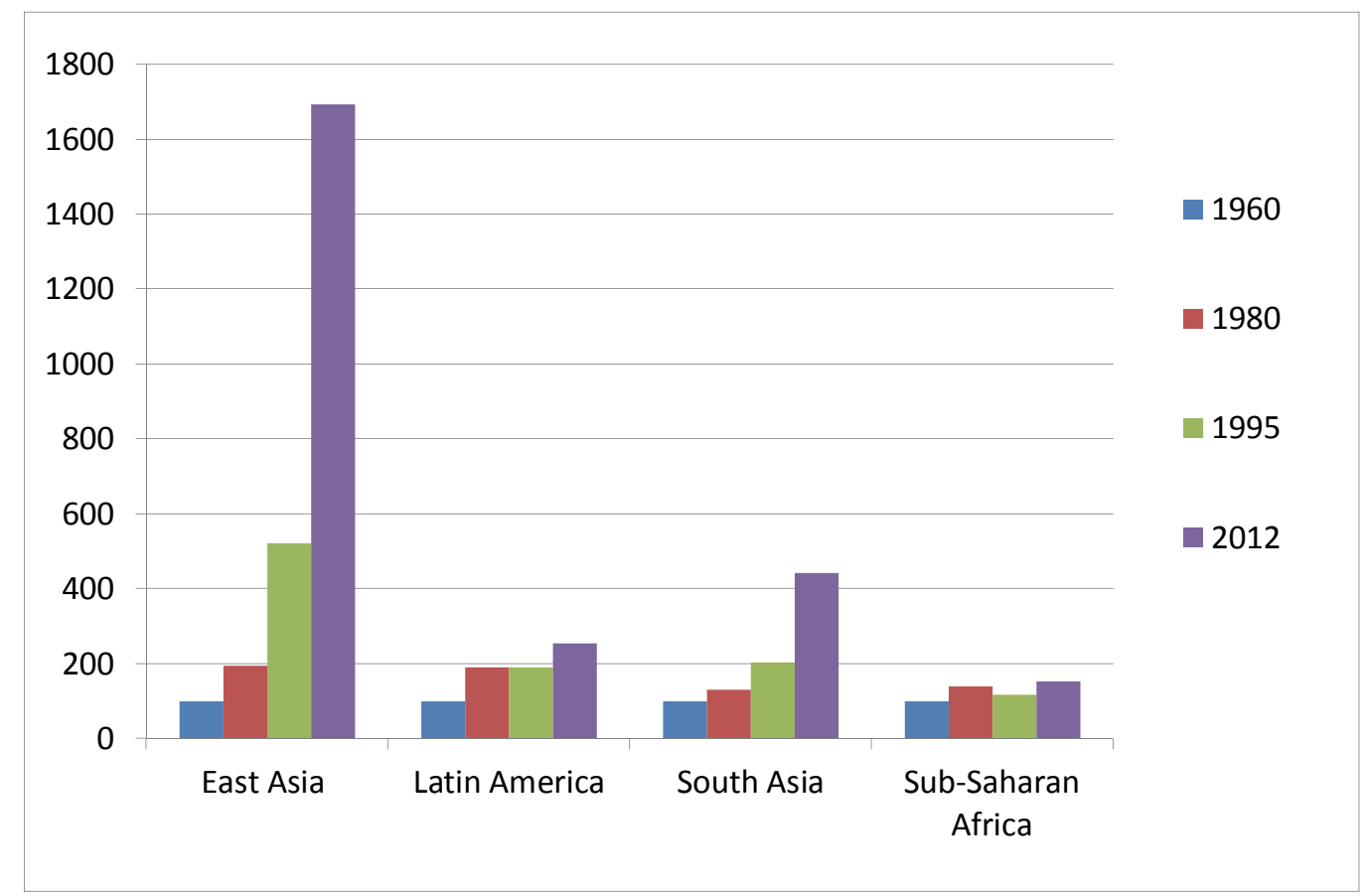

Source: World Bank (2013b).

Note: Index $1960=100$ 
Figure 2: Poverty rates, developing regions' population living on under US\$2 per day (\%)

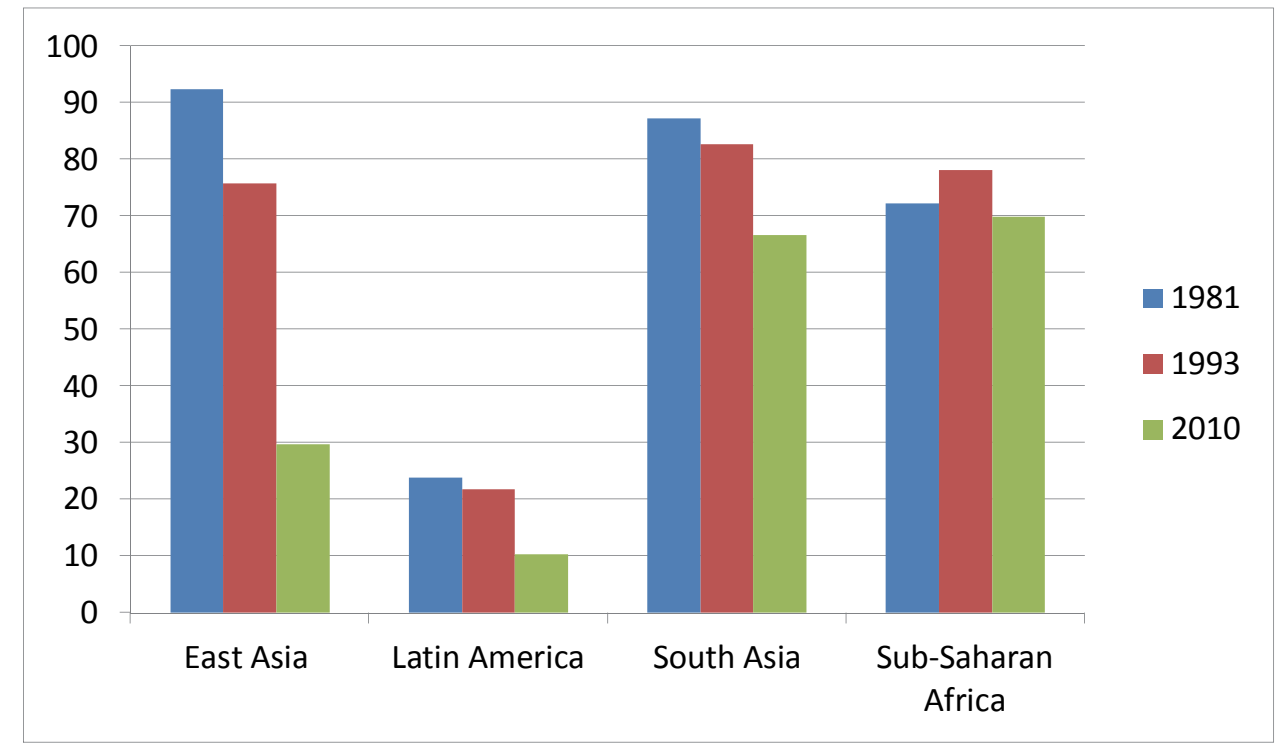

Source: World Bank (2013b).

Figure 3: Labourforce participation rates (\% of population ages 15-64)

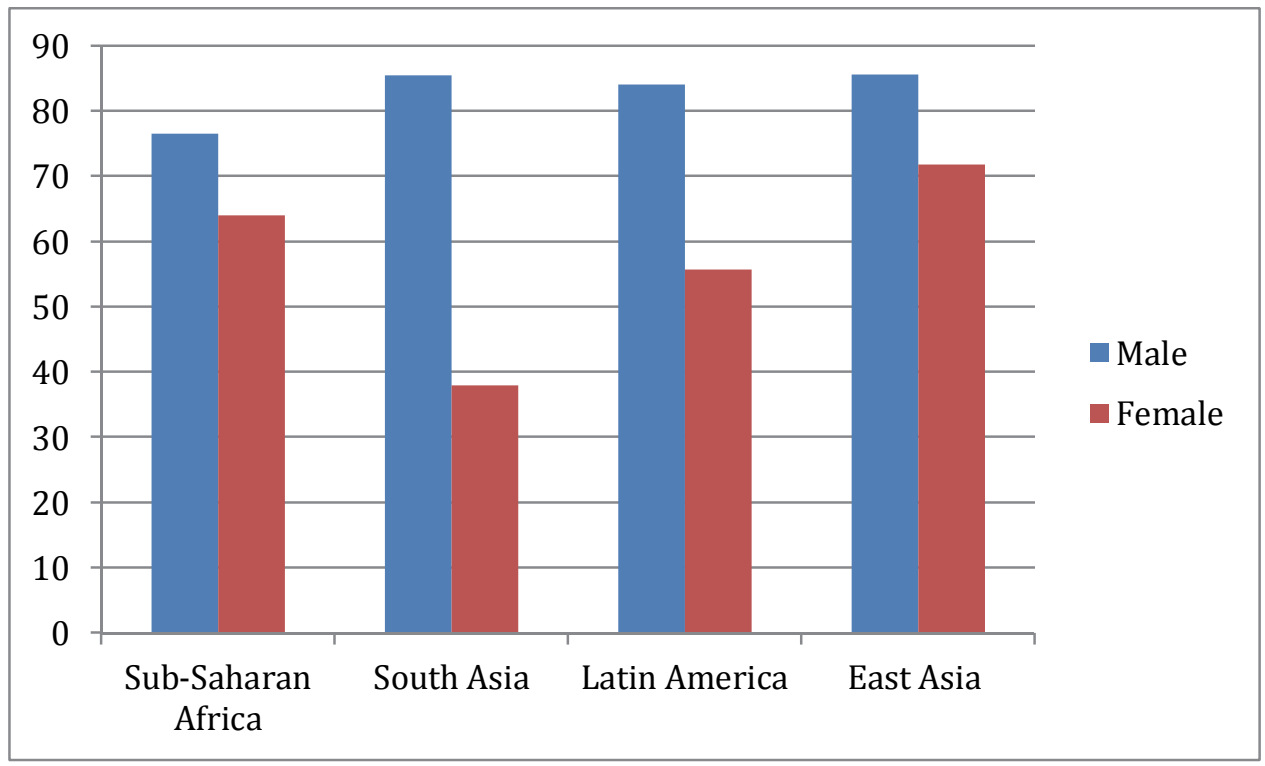

Source: World Bank (2013b). 
Figure 4: The Lewis model of labour market dualism

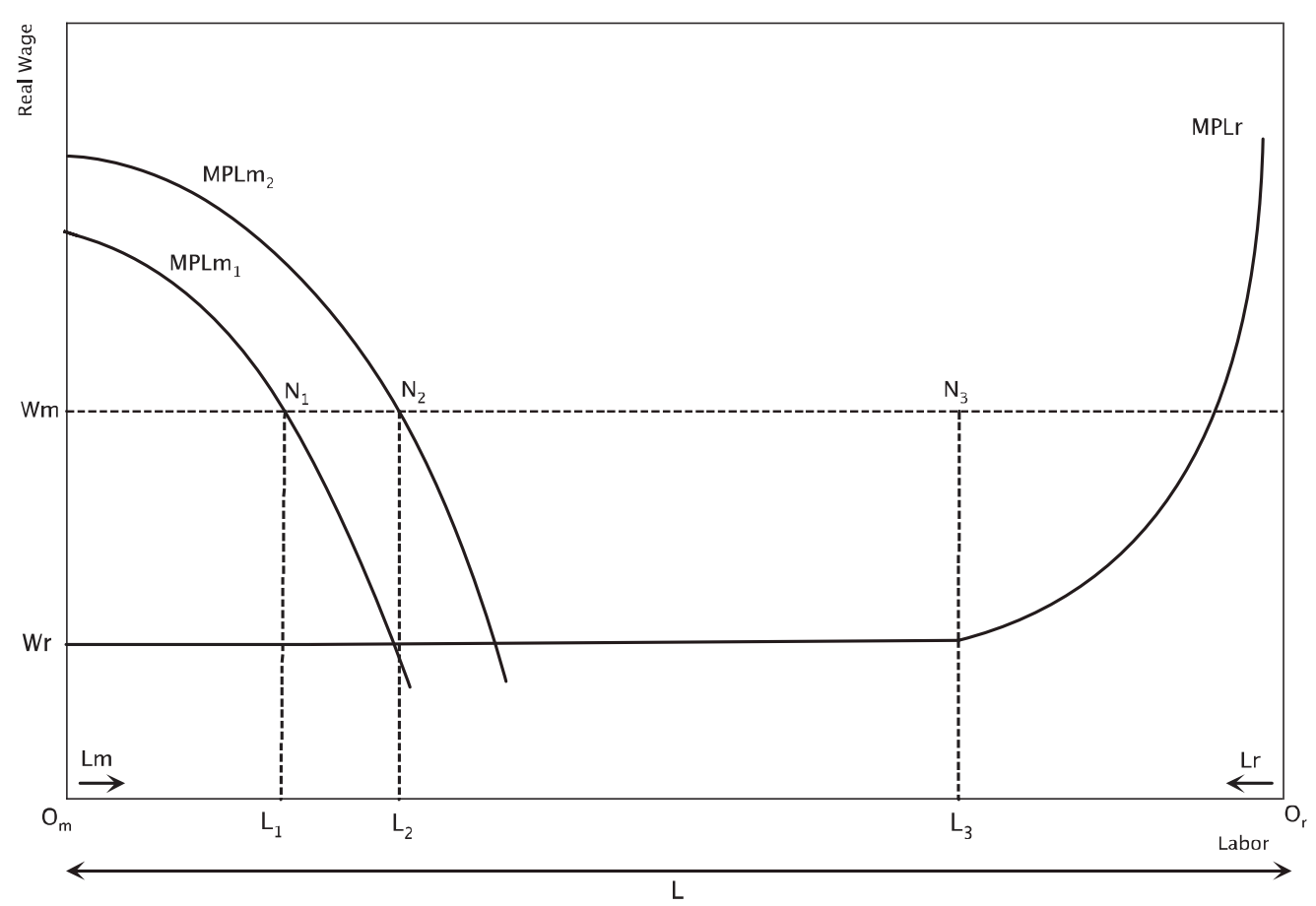

Source: Adapted from Basu (1997).

Figure 5: The Harris-Todaro model

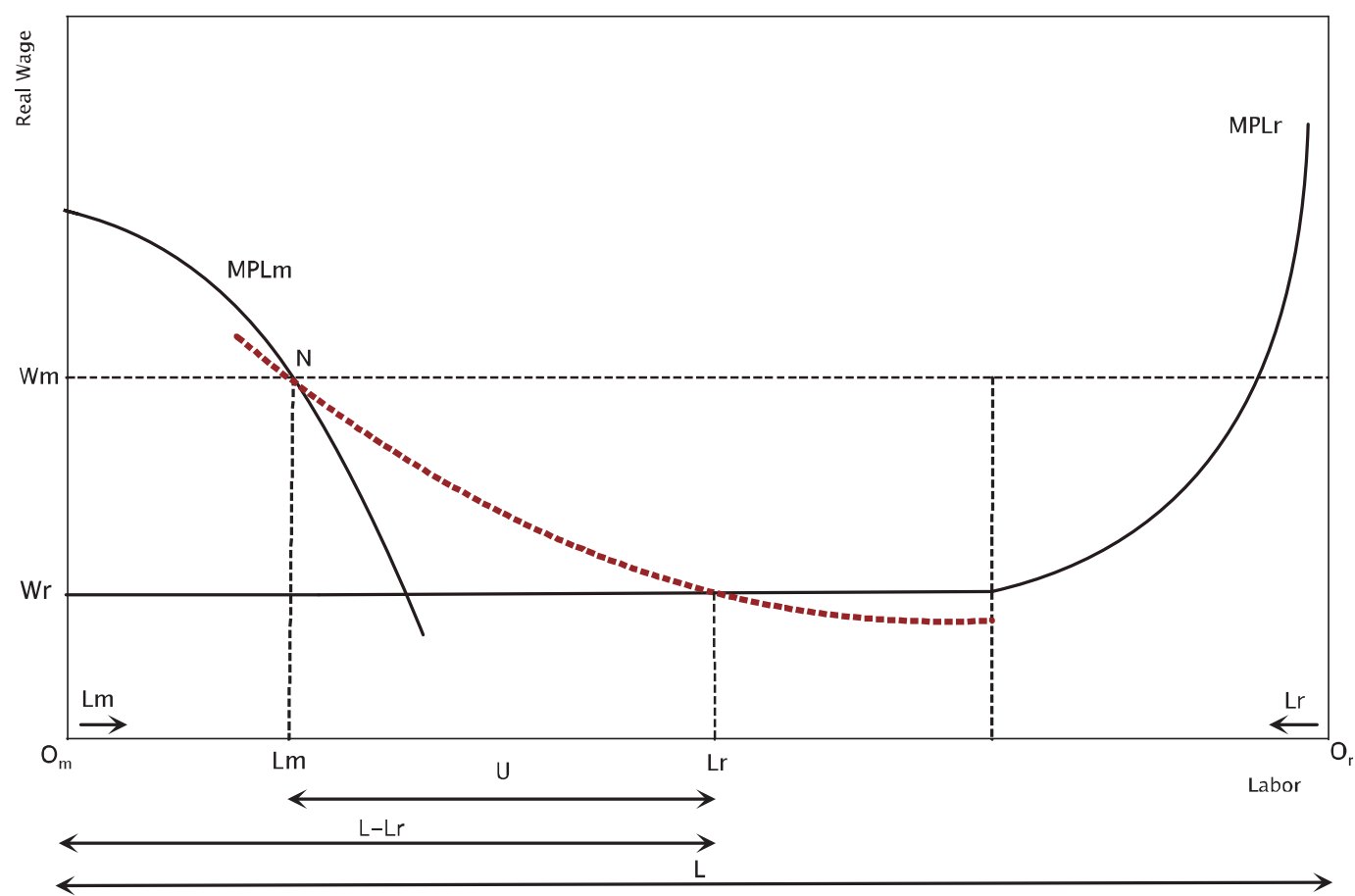

Source: Adapted from Basu (1997). 
Table 1: Distribution of employment by sector

\begin{tabular}{|c|c|c|c|c|}
\hline & $\begin{array}{l}\text { Year of } \\
\text { Survey }\end{array}$ & $\begin{array}{l}\text { Public sector } \\
\text { including state- } \\
\text { owned } \\
\text { enterprises (\%) }\end{array}$ & $\begin{array}{l}\text { Formal private } \\
\text { sector (\%) }\end{array}$ & $\begin{array}{c}\text { Informal sector } \\
(\%)\end{array}$ \\
\hline \multicolumn{5}{|l|}{ SSA low-income } \\
\hline Benin & 2005 & 2.6 & 2.1 & 95.3 \\
\hline Burkina Faso & 2005 & 4.3 & 1.0 & 94.7 \\
\hline Cameroon & 2005 & 4.9 & 4.7 & 90.4 \\
\hline Congo Rep. & 2005 & 6.3 & 1.8 & 91.9 \\
\hline Ethiopia & 2005 & 3.9 & 6.2 & 89.9 \\
\hline Ghana & 2010 & 6.4 & 7.0 & 86.6 \\
\hline Madagascar & 2005 & NA & NA & 86.5 \\
\hline Malawi & 2004 & 9.0 & 11.5 & 79.5 \\
\hline Mali & 2007 & 3.1 & 0.4 & 96.5 \\
\hline Nigeria & 2004 & 8.0 & 0.3 & 91.8 \\
\hline Rwanda & 2006 & 3.7 & 1.2 & 95.1 \\
\hline Senegal & 2001 & 1.8 & 6.1 & 92.1 \\
\hline Tanzania & 2006 & 3.0 & 1.5 & 95.5 \\
\hline Uganda & 2006 & 2.8 & 14.2 & 83.0 \\
\hline Zambia & 2005 & 5.2 & 6.8 & 88.0 \\
\hline \multicolumn{5}{|c|}{ SAA middle-income } \\
\hline Botswana & 2006 & 25.0 & 37.0 & 38.0 \\
\hline South Africa & 2007 & 16.0 & 45.6 & 38.4 \\
\hline \multicolumn{5}{|l|}{ North Africa } \\
\hline Egypt & 2006 & 30.0 & 10.0 & 61.0 \\
\hline
\end{tabular}

Sources: Benin, Burkina Faso, Senegal: Benjamin and Mbaye (2012); Ethiopia, Mali, Malawi, Madagascar, Rwanda, South Africa, Uganda, Tanzania, Nigeria: Stampini et al. (2013); Botswana: Van Klaveren et al. (2009a); Egypt: As'ad (2009); Cameroon, DRC: Razafindrakoto et al. (2009); Zambia: Van Klaveren et al. (2009b); Ghana: Data Portal Ghana (2010). 
Table 2: Unemployment rates (\% of labourforce), $2006^{\mathrm{a}}$

\begin{tabular}{lr}
\hline SSA low-income & \\
\hline Benin & 0.7 \\
Burkina Faso & 2.3 \\
Cameroon & 2.9 \\
Ethiopia & 17 \\
Ghana & 3.6 \\
Madagascar & 2.6 \\
Malawi & 7.8 \\
Senegal & 10.0 \\
Tanzania & 4.3 \\
Uganda & 2 \\
Zambia & 15.9 \\
Zimbabwe & 4.2 \\
& \\
\hline SSA middle-income & \\
\hline Botswana & 17.6 \\
Mauritius & 9.1 \\
South Africa & 22.6 \\
& \\
\hline North Africa & \\
\hline Egypt & 10.6 \\
Morocco & 9.7 \\
Tunisia & 12.5 \\
\hline
\end{tabular}

Source: World Bank 2013b.

Notes: ${ }^{\mathrm{a}} 2002$ for Benin; 2004 for Malawi and Zimbabwe; 2005 for Uganda and Zambia; 2007 for Cameroon.

Table 3: Distribution of employment by sector (share of the labourforce \%)

\begin{tabular}{|c|c|c|c|c|c|c|}
\hline & \multicolumn{2}{|c|}{ Tanzania } & \multicolumn{2}{|c|}{ Uganda } & \multicolumn{2}{|c|}{ Nigeria } \\
\hline & 1992 & 2001 & 1992 & 2000 & 1999 & 2006 \\
\hline Wage Employment & 7.9 & 7.8 & 15.3 & 13.3 & 19.5 & 12.4 \\
\hline Government & 5.7 & 3.0 & 5.4 & 3.4 & 12.5 & 7.0 \\
\hline Private & 2.2 & 4.7 & 9.9 & 9.9 & 7.0 & 5.4 \\
\hline Self Employed/Family & 10.9 & 18.7 & 7.6 & 10.3 & 30.2 & 28.1 \\
\hline Agriculture & 80.4 & 72.3 & 76.2 & 75.5 & 48.4 & 57.3 \\
\hline Unemployed & 0.8 & 1.3 & 0.9 & 0.9 & 4.6 & 3.6 \\
\hline
\end{tabular}

Sources: Kingdon et al. (2006); Haywood and Teal (2009).

Notes: For Nigeria, private wage employment includes NGOs and international organizations. 


\begin{tabular}{ccc}
$\begin{array}{c}\text { Manufacturing } \\
\text { wage/GDP per } \\
\text { capita }\end{array}$ & $\begin{array}{c}\text { Manufacturing } \\
\text { wage/manufacturing. } \\
\text { productivity }\end{array}$ & $\begin{array}{c}\text { Minimum } \\
\text { wage/GDP per } \\
\text { capita }\end{array}$ \\
\hline
\end{tabular}

Low-income SSA

$\begin{array}{llll}\text { Cameroon } & 5.0 & 0.34 & \\ \text { Ethiopia } & 6.1 & 0.20 & 0.43 \\ \text { Ghana } & 4.9 & 0.18 & 1.93 \\ \text { Kenya } & 4.7 & 0.31 & 1.31 \\ \text { Lesotho } & 2.5 & \mathrm{NA} & 1.14 \\ \text { Malawi } & 3.3 & 0.31 & 1.05 \\ \text { Senegal } & 9.4 & 0.35 & 4.36 \\ \text { Tanzania } & 4.5 & 0.23 & 0.44 \\ \text { Uganda } & 8.6 & 0.09 & \end{array}$

Middle-income SSA

$\begin{array}{llll}\text { Mauritius } & 1.0 & 0.43 & 0.17 \\ \text { South Africa } & 2.5 & 0.38 & 0.29 \\ \text { North Africa } & & & \\ \text { Egypt } & 1.8 & 0.26 & 0.41 \\ \text { Morocco } & 2.6 & 0.42 & 1.18 \\ \text { Tunisia } & 1.7 & 0.41 & 0.58\end{array}$

\section{East Asia}

Cambodia

0.33

0.77

China

Indonesia

1.1

0.15

0.54

Korea

1.4

0.22

0.49

Malaysia

1.1

0.32

0.34

Thailand

0.7

0.54

Vietnam

0.18

0.68

\section{South Asia}

$\begin{array}{llll}\text { India } & 2.4 & 0.19 & 0.68 \\ \text { Nepal } & 1.8 & 0.19 & 1.21\end{array}$

\section{Latin America}

Mexico

Source: UNIDO (2012); World Bank (2013b); authors' calculations. 
Table 5: Monthly earnings, by sector (in Euros)

\begin{tabular}{lccccccc}
\hline & \multicolumn{1}{c}{} & \multicolumn{1}{c}{ Côte } & & & & & \\
& Benin & Cameroon & d'Ivoire & DRC & Madagascar & Mali & Senegal \\
\hline Government & 137 & 217 & 337 & 18 & 99 & 136 & 228 \\
Public enterprise & 186 & 370 & 390 & 52 & 107 & 214 & 205 \\
Formal private sector & 100 & 133 & 219 & 34 & 59 & 141 & 169 \\
Informal sector & 40 & 61 & 60 & 17 & 38 & 57 & 59 \\
\hline
\end{tabular}

Source: Adapted from Roubaud and Torelli (2013, Table 1.14).

Table 6: Minimum wages, relative to per capita GDP, 2012

\begin{tabular}{|c|c|c|c|c|c|}
\hline & US\$ & $\begin{array}{l}\text { Ratio to } \\
\text { per capita } \\
\text { GDP (\%) }\end{array}$ & & US\$ & $\begin{array}{c}\text { Ratio to per } \\
\text { capita GDP } \\
(\%)\end{array}$ \\
\hline Low-income SSA & & & East Asia & & \\
\hline Burkina Faso & 61 & 115 & Cambodia & 61 & 77 \\
\hline Burundi & 42 & 198 & China & 257 & 51 \\
\hline DRC & 46 & 202 & Indonesia & 161 & 54 \\
\hline Ghana & 58 & 43 & Korea & 925 & 49 \\
\hline Kenya & 139 & 193 & Malaysia & 294 & 34 \\
\hline Lesotho & 130 & 131 & Thailand & 245 & 54 \\
\hline Madagascar & 44 & 118 & Vietnam & 90 & 68 \\
\hline Malawi & 26 & 114 & & & \\
\hline Nigeria & 115 & 89 & & & \\
\hline Senegal & 90 & 105 & South Asia & & \\
\hline Tanzania & 221 & 436 & Bangladesh & 19 & 31 \\
\hline Uganda & 20 & 44 & India & 85 & 68 \\
\hline Zambia & 218 & 178 & Nepal & 71 & 121 \\
\hline \multicolumn{6}{|l|}{ Middle-income SSA } \\
\hline Botswana & 105 & 18 & Latin America & & \\
\hline Mauritius & 112 & 17 & Dominican Rep. & 251 & 53 \\
\hline \multirow[t]{2}{*}{ South Africa } & 183 & 29 & Honduras & 358 & 190 \\
\hline & & & Mexico & 125 & 15 \\
\hline North Africa & & & Nicaragua & 144 & 99 \\
\hline Egypt & 110 & 41 & & & \\
\hline Morocco & 288 & 118 & & & \\
\hline Tunisia & 206 & 58 & & & \\
\hline
\end{tabular}

Source: World Bank (2013b); United States State Department (2013). 
Table 7: Indicators of the business climate

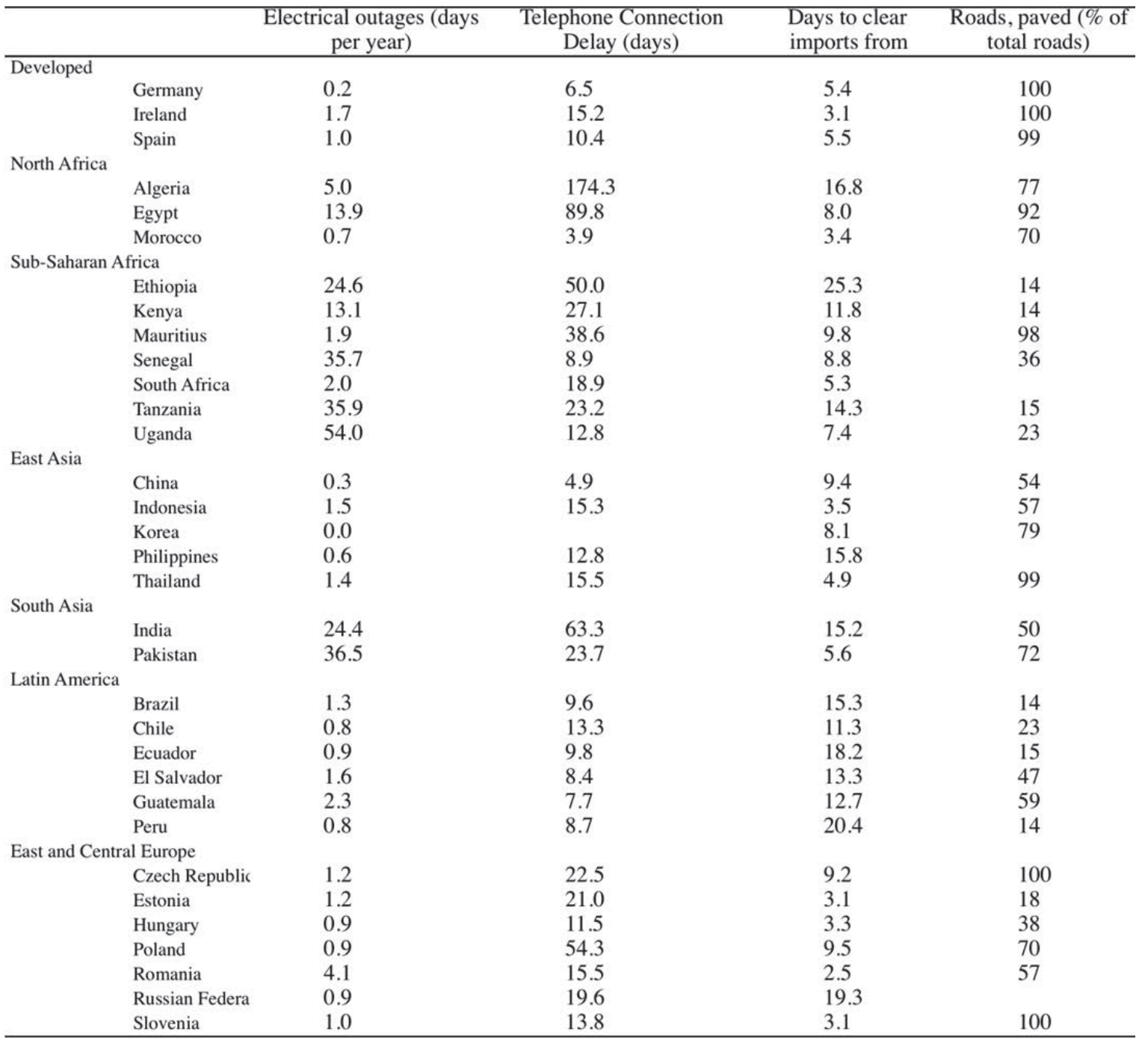

Sources: World Bank (2013a, 2013b). 